A Journal of Culture, English Language, Teaching \& Literature

ISSN 1412-3320 (Print), ISSN 2502-4914(Online)

Vol. 16 No. 2; December 2016

Copyright @ Soegijapranata Catholic University, Indonesia

\title{
FIGURING THE CONTEXT OF CTL UNDER THE 2013 CURICULUM
}

Chairina Nasir ${ }^{1}$, Ika Apriani Fata ${ }^{1}$, Bukhari Daud $^{1}, \&$ Nia Isniati ${ }^{2}$

${ }^{1}$ English Education, Faculty of Teacher Training and Education, Syiah Kuala University, Banda Aceh, Indonesia

${ }^{2}$ Freelance English Teacher at Banda Aceh, Indonesia

Ph:

$+628116833336$

Email:

rina_naseer@yahoo.com ika.unsiyah@gmail.com

bukharidaud@yahoo.com

nia.isniati@gmail.com

Received: 26-01-2016

Accepted: 23-02-2017

Published: 28-02-2017 


\title{
FIGURING THE CONTEXT OF CONTEXTUAL TEACHING AND LEARNING (CTL) UNDER THE 2013 CURRICULUM
}

\author{
Chairina Nasir ${ }^{1}$, Ika Apriani Fata ${ }^{1}$, Bukhari Daud ${ }^{1}$, and \\ Nia Isniati ${ }^{2}$ \\ rina_naseer@yahoo.com; ika.unsyiah@gmail.com; bukhari \\ daud@yahoo.com; nia.isniati@gmail.com \\ ${ }^{1}$ English Education, Faculty of Teacher Training and Education, \\ Syiah Kuala University, Banda Aceh, Indonesia \\ ${ }^{2}$ Freelance English Teacher at Banda Aceh, Indonesia
}

\begin{abstract}
The 2013 curriculum states that the purpose of teaching English for junior high school is to develop students' communicative competence. In line with this expectation, several learning characteristics have been defined i.e. learning from model, observing, questioning, gathering information, associating, and communicating. Therefore, the teaching approaches that are used by the teacher in teaching English must suit the criteria to promote students' communicative competence. Contextual Teaching and learning (CTL) seems to be compatible as an approach since it has the the characteristics of constructivism, questioning, inquiry, learning community, modelling, reflection, and authentic assessment, which are similar to the learning characteristics mentioned above, which are similar to the learning characteristics mentioned above. , which are similar to the learning characteristics mentioned above. Therefore, a qualitative research concerning the issue was conducted to see how CTL approach is implemented under the 2013 curriculum in teaching reading comprehension. From the result of observation, questionnaire, and interview as the instruments, it was found that CTL was implemented properly from phase to phase and is applicable to be implemented under the curriculum. Also, it promotes active and enjoyable learning, facilitates the students to comprehend the material and helps them to implement the knowledge in real life. The. The teacher had implemented all of the procedures of CTL under the
\end{abstract}


instruction of the 2013 curriculum. Thus, applying the CTL CTL approach in the process of teaching for the 2013 curriculum for the 2013 curriculum is recommended since it gives satisfactory benefits for students.

Key words: CTL, teaching reading comprehension, teaching reading comprehension, the 2013 Curriculum.

Abstrak: Kurikulum 2013 mengamanahkan bahwa siswa tingkat Sekolah Menengah Pertama wajib mengembangkan kompetensi komunikatif. Sejalan dengan tujuan pendidikan tersebut, berbagai macam teknik pembelajaran dikembangkan seperti learning from model, observing, questioning, gathering information, associating, and communicating. Oleh karena itu, dalam proses belajar mengajar, seorang Guru bahasa Inggris, contohnya, wajib menyesuaikan teknik belajar untuk mencapai tujuan kompetensi komunikatif tersebut. Pembelajaran kontekstual diasumsikan dapat mengaplikasikan konsep konstruktivisme (constructivism), bertanya (questioning), menemukan (inquiri), masyarakat belajar (learning community), permodelan (modeling), refleksi (reflection) dan penilaian yang sebenarnya (authentic assessment). Penelitian ini bertujuan untuk menganalisa penerapan pembelajaran kontekstual dengan kurikulum 2013. Metode penelitian ini adalah kualitatif. Hasil penelitian ini menunjukkan berdasarkan observasi, kuesioner dan wawancara bahwa pembelajaran kontekstual (CTL) pada kurikulum 2013 diimplementasikan secara bertahap sesuai dengan prosedurnya. Di tambah pula, pendekatan kontekstual berhasil membuat siswa aktif dan menikmati suasana belajar serta dapat merelasikan dengan kehidupan sehari-hari. Dengan demikian, direkomendasikan penggunaan pendekatan kontestual dalam pengajaran membaca dalam Bahasa Inggris dengan kurikulum 2013.

Kata kunci: Pembelajaran Kontestual (CTL), Pengajaran Membaca dalam Bahasa Inggris, Kurikulum 2013.

\section{RESEARCH BACKGROUND}

The purpose of teaching English in Indonesia under the 2013 curriculum is to develop students' communicative competency in English both oral and written language. The communicative competence includes linguistic competence, actional competence, socio-cultural competence, and strategic competence. According to Celce-Murcia, Dôrnyei \& Thurrel (1995) 
learners with linguistic competence are able to master the pronunciation and spelling rules. They are also keen on the rules of word forms, rules of standard sentences, rules of vocabulary, and rules of meaning. Actional competence that that takes place in in language is used to communicate people's actions. In speaking, people can request service, give praise, ask for information, and so forth. While in writing, people also commit acts of language, such as writing the context of the scene, told a number of events, and leave a comment. Language users with socio-cultural competence understand the context of using the language. They are also capable of using expressions and act acceptably in various context of communication. Strategic competence refers to the mastery of using the language that includes knowing how to start, stop, maintain, repair, and redirect communications. In other words, this competence demonstrates the the ability to solve problems that arise in the communication process in various ways so that the communication is running smoothly.

According to Richard and Rodgers (2007) communicative competencies includes: (1) knowing how to use the language for any purposes, (2) knowing the variety use of language based on the background of interlocutor, (3) knowing and understanding the various kind of texts (narrative, interview, conversation, etc.), (4) knowing how to keep conversation going on by using communication strategy though with limited knowledge of language understanding. These competencies are aligned with the purpose of learning language in the 2013 curriculum (Kemendikbud, 2014).

To realize those expectations, the 2013 curriculum (Kemendikbud, 2014) adopts the teaching principles, such as: (a) making real communication as the focus of language learning, (b) giving opportunity to the learners to experiment and try out all of the competences they have, (c) mistakes are counted as a process of learning, (d) giving chance to the learners to expand their fluency and accuracy, (e) relating all language skills all together as happen in real life, (f) and facilitating the learners to find the rule of the language by themselves. All of those principles are encompassed in four language skills namely listening, speaking, reading, and writing. One of the skills mostly included in examination is reading since by means of reading, students' understanding of the target language can be predicted and accumulated.

Grabe and Stoller (2002) as cited in Tindale (2003) define reading as the skill that might draw meaning from the pointed page and interpret the 
information contextually. It means that by means of reading the students do not only obtain the knowledge and experience but also comprehend the meaning of the whole sentences by understanding every element in reading such as syllable, pronunciation, punctuation, and how to get the information. Thus, they can infer what the reading text is about.

Mikulecky and Jeffries (1996) convey that reading becomes important since reading enlarges vocabulary and help to bring about the essential foundation in learning and seeking information and knowledge in real life situation. Students' reading comprehension of a text can be reflected on their ability to answer comprehension questions of the text. The students' ability in mastering reading comprehension does not only depend on their knowledge in reading technique, but also the approach used by the teacher in teaching reading process. It indicates that the approach applied by the teacher in teaching has a great impact on students' motivation and achievement in learning.

One of the approaches which can be applied by teachers in increasing students' reading comprehension is CTL (Contextual Teaching and Learning). It is an approach emphasizing on the learning process which is related to the real experience of the students. Since the principles of CTL mainly focus on learning through associating the materials with the real life experiences in the process of learning involving questioning, inquiry, modeling, learning community technique, etc., they are closely related to the characteristics of the 2013 curriculum employing the principles, such as questioning, gathering information (closely related to inquiry), associating, learning through model, etc. Hence the students can internalize the meaning of the subject they learn through the experiences they ever have.

The effectiveness of CTL approach in teaching reading has been proven through several researches. One of them is an experimental research conducted by Haryati (2012) to 23 first grade students of Al Irsyad Satya Islamic School Padalarang, Bandung, West Java, which leads to the result that CTL approach is effective to improve the students' reading comprehension. Another research regarding the implementation of CTL approach was carried out by Muhlison (2011) towards the second-grade students of MTs At-Thosari Kalirejo, Ungaran Timur. In this research, it was found that CTL approach succeeds in developing reading comprehension. From both studies, it can be interpreted that CTL is one of the approaches which can bring students to be more aware of the meaning of what they read which increases their comprehension. However, there is a question that 
might emerge in accordance with the implementation of the CTL approach under the curriculum i.e. are teachers able to implement the CTL approach properly and adjust it to the procedure of the 2013 curriculum. This issue encourages the writer to do a further study on how the CTL approach is implemented in the classroom under the instruction of the 2013 curriculum. To date, there has been no research to figure out CTL approach under 2013 curriculum at any junior high school in Aceh, therefore this study would fill in this gap.

\section{RESEARCH PROBLEM}

This research promotes the research question: how is CTL approach implemented in teaching reading comprehension under the 2013 Curriculum.

\section{REVIEW OF LITERATURE}

\section{A. Contextual Teaching and Learning (CTL)}

The concept of CTL was firstly introduced by John Dewey (1900) through his research based on his belief that students will learn something well if what they learn is related to events happened in their environment or something they have been experienced. According to Bern and Erickson (2001), CTL is one of the the conception of teaching and learning that helps teachers relate subject matter content to real world situations that motivates students to make connections between knowledge and its applications to their lives as family members, citizens, and workers and engage in the hard work that learning requires. This definition implies that CTL is an approach which relates the learning process to the students' daily lives experiences and it helps to encourage them in acquiring the skills/subject taught since it brings the students to connect their knowledge to the real life situation. Therefore, it is also called as contextual approach. This notion is in line with Johnson's idea (2002) stating that the aim of CTL approach is to assist students in realizing the meaning of the materials they are learning by connecting them to the context of their daily lives.

CTL consists of seven main components which are also labeled as the principles of the method. Those components are clarified by Department of National Education (2003) as follows: 
1. Constructivism. Knowledge is not merely facts, concepts, or rules which can be accepted or memorized that simply, but it needs to be connected to real life experiences, hence, the knowledge can be constructed and understood. That is why learning process must be formed as construction knowledge, not as receiving process.

2. Questioning. It is a strategy to check students' background knowledge, encourage students' response, guide and focus their attention on the material, and assess students' aptitude in thinking.

3. Inquiry. A process of searching and finding the knowledge/understanding through systematic thinking. Thus, through the process, students can build their creativity.

4. Learning Community. This concept emphasizes that the result of learning must be obtained from working with others like pair or group sharing.

5. Modeling. A concept to display/present a symbol or role model as a sample for students in the process of learning.

6. Reflection. It is a form of feedback given by the teacher at the end of the meeting toward the activities or knowledge.

7. Authentic Assessment. A process of collecting all data regarding students' learning development to identify their progress. This assessment is based on the real work of students (skills and attitude) evaluated during or after learning process.

These seven components are important because they ensure language learners involve actively in the teaching and learning process. By participating, learners can relate what they already know with the new knowledge that helps create meaning and understanding of the language.

\section{B. Reading Comprehension}

Reading comprehension cannot be separated from reading skill since without comprehending what is being read, message/information conveyed can never be extracted. Pang, Angaluki \& Michael (2000) describe comprehension as the process coming from connecting meaning of the words or phrases in the text read. They further clarify that reading comprehension is an active process that depends not only on comprehension but also on understanding the vocabulary, seeing the relationship between words and concepts, organizing ideas, and evaluating in making judgments. In order to understand the text given, the reader must be able to identify words rapidly, know the meaning almost all of the words and be able to 
combine units of meaning into a coherent message. In short, reading comprehension is readers' ability to incorporate the meaning of all words and phrases in a text read, understand the ideas, and make a conclusion from all of the ideas to be interpreted as the whole message informed by the writers. Consequently, reading comprehension becomes a standard of successful readers.

\section{The 2013 Curriculum}

The 2013 curriculum is the curriculum that is that is introduced officially by the government in 2013 as a substitute of KTSP/Kurikulum Tingkat Satuan Pendidikan (School-based Curriculum). Fata and Nasir (2014) stated that based on their understanding of the 2013 Curriculum Document published by the Ministry of Education (2013), the curriculum development objective is to achieve competence formulated from the graduates' standard of competencies (Standard Kompetensi Lulusan/SKL). In other words, the learning and curriculum outcomes are measured from the achievement of competence. Previously in KTSP, the national standard; Standard Kompetensi Lulusan/SKL (Graduates Standard Competence) is translated into Standard Kompetensi (SK) and Kompetensi Standard (KD), meanwhile in 2013 curriculum, the graduates' standard competence is applied into Kompentensi Inti or Core Competence and Kompetensi Dasar or Basic Competence. Beside the change in graduates' standard of competencies, the core competence stands into four integrated groups namely Religious Attitudes, Social Attitudes, Knowledge and Knowledge Implementation.

Those four groups of Core Competences should be applied in every school subjects as one; it is -called Thematic Integrative Approach. The religious and social attitudes (the first and the second competences) are taught indirectly while teaching the third and fourth competences as these competences shape students' character building. Another important characteristic of the curriculum is the scientific approach that is applied for all majoring classes (Science and Math, Social Science and Language major) in which observing, questioning, experimenting, associating and communicating involved. In learning language, the curriculum follows the principle of communicative approach emphasizing in providing students with real or natural situations (activities in learning) which encourage and lead them to be able to use the target language communicatively. This principle stresses students to learn in the situation offering authenticity, 
interaction, student-centered, task-based activity, and real communication (Brown, 2007 cited in the manual book of the 2013 curriculum).

\section{RESEARCH METHOD}

The study used is qualitative in nature by investigating the implementation of CTL in the reading comprehension subject under the 2013 curriculum. The data were gathered through observation, questionnaire and interview. This research was carried out at public junior high school (SMPN) 18 Junior high school in Banda Aceh of the second-grade students.

\section{DISCUSSION}

\section{A. The Observation Result of the Teacher's Activity}

In pre-activities, the teacher firstly opened the class by greeting the students and checking the attendance list. In order to construct students' mind regarding the topic they were going to learn, the teacher asked the students if they have ever seen any announcement in their daily life and what kinds of announcement they have ever read.

This session was intended in order in order to connect the topic with the students' the students' background knowledge from real life experience; hence the students could absorb the the information given by the teacher by the teacher easily. In CTL, this activity is called Constructivism. The questioning activity was done by asking some questions to encourage students' responses such as what is the text about, what is the announcement about, to whom is the announcement intended and also what is what is the meaning of some new words.

These pre-activities took about 10 minutes. After passing this session, the teacher started to write an announcement on the whiteboard and the material he thought thought appropriate to the students. These students seemed interested since they showed excitement. These students seemed interested since they showed excitement about the the learning activity. activity.

After showing the example of an announcement text, the teacher asked the students to find the main gist of the text as well as the detail information (Inquiry). Then he instructed the students to find the unknown vocabulary in context by giving them guidance and model on how to do it (Modeling). 
Fortunately, even if he did not instruct them them to work in a community, the students did work with their nearest partner. This could be counted as learning community. When the activities were finished, the teacher started to assess the students personally by asking the meaning of words and several comprehension questions. Also, the teacher used a strategy of getting a fast score that made the students very enthusiastic in it. The core-activities took about 60 minutes. After finishing the teaching activity, authentic assessment was done by asking students to find and read another kind of announcement in post-activities work which took about 10 minutes.

\section{B. The Observation Result of the Students' Activity}

Based on the observation sheet, students showed how they showed how they paid attention to the teacher's explanation regarding the topic they were going to learn and has has observed well well the sample shown on the whiteboard as the media. When the teacher constructed their mind and asked the questions about the material displayed, the students actively participated in answering the questions. Since the teacher knew how to attract the students' attention, they became really motivated in the learning process. In the core activities when the teacher wrote down an example of an announcement on the whiteboard, the students copied the text on their notebooks. Then they tried to find the general ideas and the details information of the announcement text as the teacher asked.

Afterward, the students began to analyze the vocabulary and find the meaning in context as guided or the model given by the teacher. After taking some times in these activities, the teacher started asking questions in regard to the announcement text and the students tried to answer the questions such as how to pronounce the certain words, the meaning of the words, and other comprehension questions.

In the post activities, the students made a self-evaluation as instructed by the teacher. For instance, the students responded to the teacher's questions such as: how many new words did you get from the text you just read, was there any difficulty you found during the learning process, etc. After that, the students listened to the feedback given by the teacher and wrote down the homework assigned.

\section{Result of Questionnaire}

The questionnaire distributed to the students consists of two parts, namely learning process and comprehension part. Each part respectively 
comprises of six and five statements in which the statements represent all of the activities proposed by the teacher to deliver the material and to help the students in understanding it. Furthermore, for each statement, there are three options for the students to choose whether they agree, less agree, or disagree and the reason for their choices. All of their answers were based on their experience during the teaching and learning process. The result of the questionnaire is described as follows.

\section{Learning Process}

For the first part of the questionnaire, the learning process consists of six statements. First, it is shown that $78.3 \%$ agree that the learning process became more interesting and enjoyable by using CTL in reading comprehension subject. Second, $70 \%$ of the students agree that the use of media/realia applied motivated them in observation process as expected in the 2013 curriculum. Third, 100\% students totally agreed that the learning process became more active in discussing, asking, and giving opinion when the CTL approach was implemented. Fourth and fifth, equally, $91.3 \%$ of the students think that reading material given by the teacher was interesting and the activities were also motivating and encouraging in the learning process. Sixth in the last statement on providing assessment toward the students' effort in earning $100 \%$ points.

\section{E. Comprehension}

For the comprehension part of the questionnaire, $60.9 \%$ students agreed that the process of learning helped them in understanding the reading material including all aspects of reading. Additionally, $87 \%$ of them concurred that the learning process/activities proposed by the teacher assisted them to see the link of what they learned in their daily life. The $87.3 \%$ of the students admitted that the activities in the learning process facilitated them in applying the knowledge they earned in their real life.

In terms of the assessment given by the teacher, most of the students or 91.3\% agreed that it helped them to comprehend the materials better. There were also $95.7 \%$ of them, who also concurred that the assignment assigned by the teacher assisted them in comprehending the materials taught. The clear outlook of all of the questionnaire's result above (in percent) is depicted in the following table. 
Nasir, C., Fata, I.A., Daud, B., \& Isniati, N., Figuring the Context of

Contextual Teaching and Learning (CTL) under the 2013 Curriculum

\section{Table 1}

The Result of Students' Questionnaire

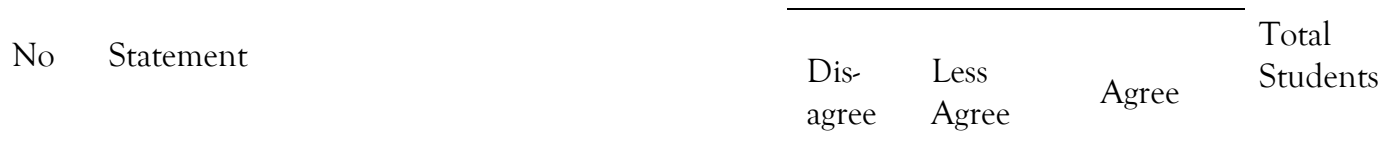

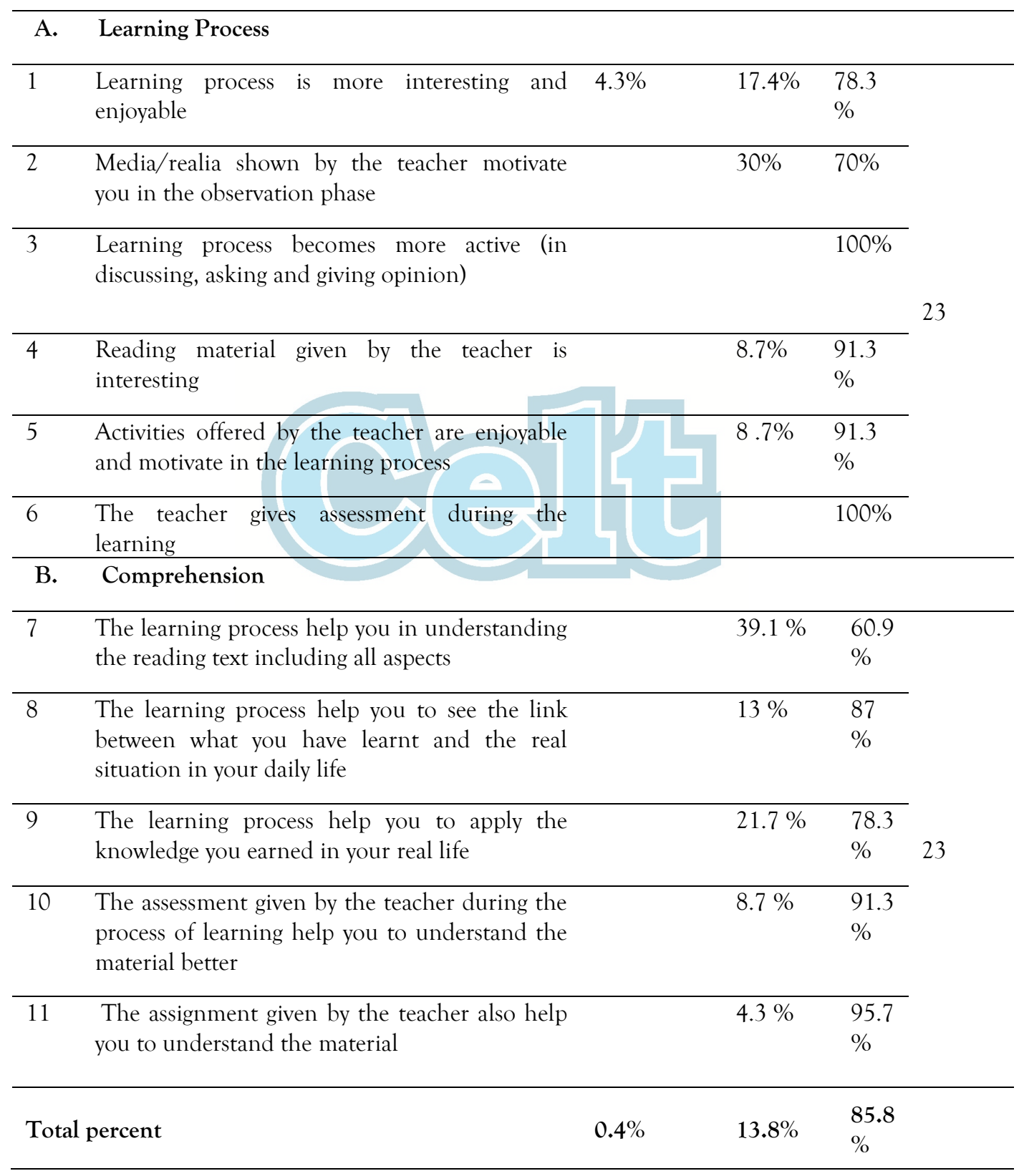




\section{F. Result of Interview}

In reference to the appropriateness of the CTL approach to be applied under the 2013 curriculum, the teacher agreed that the CTL approach is suitable and relevant since the curriculum stresses students to learn in context and all elements of CTL are encompassed in the instruction of the curriculum. Besides, the curriculum emphasizes on applying strategies which can promote students' activeness in communicating and they can apply what they learned in real life situation.

Additionally, the teacher noticed that the students were more involved and excited about learning. The teacher also acknowledged that the students' activeness and comprehension depend closely on the way of the teacher in using proper strategy, creating a better atmosphere and mutual communication. In terms of the students' learning result, the teacher admitted that the students gained better as their comprehension and could answer the questions posed correctly.

\section{CONCLUSION}

To conclude of what has been found during the investigation, it is better to restate the aim of this study. That is, to discover how CTL approach is implemented in teaching reading comprehension at this school in Banda Aceh under the instructions of the 2013 Curriculum.

Based on the result of the three kinds of the data collected (observation, questionnaire, and interview), it can be summarized that the teacher has s implemented all procedures of the CTL approach in reading comprehension of functional text as suggested by Department of National Education started from constructing students' mind and background knowledge (Constructivism), then asking several questions to encourage students' response (Questioning), instructing to find the main gist, details, and words meaning (Inquiry), giving model in finding words meaning in context (Modeling), Learning Community was done by students' initiative. Students also provided feedback of what they learned (Reflection), and Authentic Assessment is done in the process and after learning. 


\section{REFERENCES}

Berns, R.G., \& Erickson, P. M. (2001). Contextual Teaching and Learning: Preparing Students for the New Economy. The Highlighted Zone Research @Work. 2(5).1-8.

Brown., H.D. (2007). Principles of Language Learning and Teaching. New York: Pearson Education Inc.

Celce-Murcia, M., Dôrnyei, Z., \& Thurrel., S. (1995). Communicative Competence: A Pedagogically Motivated Model with Content Specifications. Applied Linguistics, 6 (2), 5-35.

Department of National Education. (2003). Pendekatan Kontekstual (Contextual Teaching and Learning-CTL). Jakarta: Depdiknas.

Dewey, J. (1900). The School and Society. Chicago, IL: University of Chicago Press.

Fata, I.A., \& Nasir, C. (2014). Current Issues of 2013 Curriculum in Indonesia. Banda Aceh. Unpublished.

Grabe., W. \& Stoller., F.L. (2002). Teaching and Researching Reading. London: Pearson Education Longman.

Haryati, N. (2012). Teaching Reading Using Contextual Teaching and Learning Approach in the First Grade of Al Irsyad Satya Islamic School Padalarang Bandung Jawa Barat. Bandung: STKIP Siliwangi Bandung.

Johnson, E.B. (2002). Contextual Teaching and Learning: what it is and why it is here to stay. London: Routledge Falmer.

Kemendikbud. (2014). Kurikulum 2013. Jakarta: Depdiknas.

Mikulecky, S. B. \& Jeffries, L. (1996). More Reading Power: Reading for Pleasure, Comprehension Skills, Thinking Skills, Reading Faster. Boston: AddisonWesley Publishing Company, Inc.

Muhlison. (2011). The Effectiveness of Contextual Teaching and Learning to Teach Reading Comprehension (An Experimental Study at the Eighth Grade Students of MTS At-Thosari Kalirejo Ungaran Timur) in Academic Year 2010/2011. Thesis: Faculty of Tarbiyah State Institute for Islamic Studies Walisongo Semarang. 
162 Celt, Volume 16, Number 2, December 2016, pp. 149-162

Pang, S. E., Angaluki, M.E. \& Michael, L. K. (2000). Teaching Reading. Chicago: IAE Education Practice Series.

Richards., J. C. \& Rogers, T.S. (2007). Approaches and Methods in Language Teaching.Second Edition. Cambridge: Cambridge University Press.

Tindale., J. (2003). Teaching Reading. Sydney: National Centre for English Language Teaching and Research. 